\title{
Future Risk Assessments of E-waste in Kurdistan Region of Iraq
}

\author{
Sarhan S. Dawood \\ Department of Computer Sciences, college of Science, University of Duhok, Kurdistan Region, Iraq
}

\begin{abstract}
Technical development in the field of electronics exceeded all expectations in terms of production and innovation, which made human life captive to electronic devices such as mobile phones, computers and their peripherals, TVs...etc. This increasing growth in quantity of these devices and their relatively short life-cycles has led to excessive accumulation of E-waste end up as landfills. Due to a large amount of toxic substances of these E-wastes, there are huge alarming hazards on the environment and human health. Some of these E -wastes contain materials such as Mercury, lead, cadmium, phosphorus and other hazardous substances which have serious impacts on the environment and human health. This research has carried field-study to investigate the magnitude of the E-waste and the scale of the impact to the environment and health in the Duhok Governorate in Kurdistan region of Iraq. The study proposes appropriate solutions to E-waste recycling and minimizes its negative impact.
\end{abstract}

Keywords: life-cycle, hazardous substances, E-waste, Kurdistan Region, recycling

\section{Introduction}

1 The Industrial revolution and developments in the electronic devices and information technology radically has changed the lifestyle of human beings. This revolution involves new design of computers and electronic devices with high level of functionality and reasonably cheap price, thus most people can purchase. This led to widespread use of these e-devices.

Unfortunately, the prosperity that has been achieved by these developments imposed some unwanted impacts on human life. These impacts involve the huge accumulations of the electronic devices wastes (ewaste) and the difficulty in getting rid of these accumulations (Acharya and Kern, 2015). Millions of tons of e-waste are generated worldwide (developed

Academic Journal of Nawroz University

(AJNU) Volume 8, No 4 (2019).

Regular research paper : Published Oct 2019

Corresponding author's e-mail : sarhan.s@gmail.com

Copyright (C2018 Sarhan S. Dawood.

This is an open access article distributed under the Creative

Commons Attribution License. and developing countries) yearly with lots of toxic and harmful substances create many environmental problems and risks on human health. However, in developing countries such as Iraq the problem of ewaste could be more dangerous as a result of experience lacking in recycling these e-waste and treating problems such as polluting of water, air and soil and their risks on people's life. In addition, developed countries sometimes do not comply with the international agreements for the management of unwanted disposal and move these e-wastes to the regions of developing countries. These make developing countries facing the danger of the toxic of some heavy metals including arsenic, lead, mercury, nickel and zinc in the e-waste.

Therefore, investigations in this direction are necessary and settling innovative plans to produce effective ecofriendly (green) products that do not harm the environment become one important goal to overcome the problem of electronic devices both, during the use 
of these devices and after their end-of-life (e-waste). This may demand the utilization of some substances such as, silver, copper, and nickel that can be found in these devices when recycled. These green products when in use help to conserve energy and to minimize carbon footprint or the emission of greenhouse gases without any drawbacks such as the production of substantial toxicity or pollution to the environment. Moreover, the other green products are biodegradable, recyclable or compostable hence, they do not harm the environment or upset the ecological balance when they are disposed. However, some green products when recycled will reduce the amount of waste sent to landfills and incinerators (http://www.all-recyclingfacts.com/eco-friendly-products.html).

\section{WHAT Is E-WASTE}

Waste, refers to anything that is no longer privately valued by its owner or has reached its end-of-life (Richard, 2002). Electronic Waste, E-Waste, E-Junk, ETrash and Waste Electronic and Electrical Equipment (WEEE) are frequently used as synonyms referring to an end-of-life electronic product that has ceased to be of any value for its owner. In this paper E-Waste is used because it is the most common terminology used.

Based on this general concept of waste, the e-waste can be defined as the popular name for discarded electrical and electronic equipment's with all of their peripherals that reached at the end of their life. E-waste comprises of wastes generated from used electronic devices and household appliances which are not fit for their original intended use and are destined for recovery, recycling or disposal. Such wastes encompasses wide range of electronic devices such as computers and their peripherals, hand held cellular phones, personal stereos, including large household appliances such as refrigerators, air conditioners etc. (Richard, 2002).

The two main issues of contention can be illustrated by the following two questions:

- What constitutes an electronic appliance?

- When does an appliance become waste?

Referring to the first question, often e-waste is restricted to old electronic products like computers and its peripherals, printers, cellular phone, large household appliances ... etc. Distinction between brown and white goods is blurred when one considers an oven with an electronic control panel. As a result, most legislation treats both discarded electrical and electronic equipment as a largely similar and overlapping waste stream. According to the Basel Action Network(BAN), "E-waste encompasses a broad and growing range of electronic devices ranging from large household devices such as refrigerators, air conditioners, and cell phones, to computers which have been discarded by their users" (Puckett, et al., 2002). While this definition gives an indication of what could be the constituents of e-waste a more precise definition is necessary not only for legal, but also for practical purposes. Thus, a more rigorous definition of e-waste could be any appliance using an electric power supply that has reached its end-of-life (Harjula, 2003)

Rose \& Stevels, attempts to answer the second question regarding when a product reaches end-of-life? Their definition states that a product's end-of-life is "the point in time when the product no longer satisfies the initial purchaser". However this does not accommodate appliances which have reached the end-of-life for their initial purchaser, but are still useful to second or third hand buyers. Just because the utility of a durable good has fallen to zero for its current owner, it does not mean that it holds no positive value for anyone else.

Hence, according to these two main issues, the e-waste can be defined as "an electrically powered (running on electricity or a battery) appliance that no longer satisfies the current owner (still in working or non-working 
condition) for its original purpose".

Therefore, electronic devices become of waste in the case of the following situations:

- When the device becomes unemployed or has been damaged and breakage.

- When the device reached to the end-of-life for the consumer.

- When the device is in good condition and performs its work, but the consumer wants to replace it with a new device more sophisticated with better capabilities

\section{E-WASTE RISKS}

From outside, electronics look clean, but beneath the smooth surface, the electronics contain toxic chemicals if thrown in the trash it will leaks on to the soil, water and Evaporate to the air and therefore it will be a danger factor on the environment and cause health problems on humans life (Jailer and Lara-Meloy and Robbins, 2015)

For this reason, E-waste become an enormous and growing problem for countries (including Kurdistan region) especially With classifying the e-waste as toxic and dangerous wastes, and hence the collecting, processing and cleaning up these waste will cost to any local government billions of US dollars to overcome their problems on environment and citizens health or it will continue to grow at an accelerated rate and hence the problem will be greater and difficult to be solved. For that, over the last two decades, the Silicon Valley Toxics Coalition (SVTC) has advocated for electronics companies to reduce the use of toxic chemicals in the design and manufacturing of their products.

In World Summit on the Information Society (WSIS) forum held Geneva, May 2015, a systematic review by World Health Organization (WHO) showed that increases in spontaneous abortions, stillbirths, premature births, and reduced birth weights, are associated with exposure to e-waste (Noël and Drisse, 2015).

In Geneva, 12 march 2012, international cooperation in the field of the wise management of e-wastes had been confirmed with the signing of an agreement between the secretariat of the Basel Convention (SBC) and International Telecommunication Union (ITU) aimed to protecting the environment and human health from the negative effects of e-waste resulting from the generation, management, Cross-border movements and disposal of their hazardous. The rapid spread of ewaste has raised public attention on this type of waste and its risks on the environment and human health (Acharya and Kern, 2015).

E-Waste risks on environment and public health can be classified on the following:-

\section{a. Risks of toxic components on both health and environment}

Hazardousness of e-waste is that it contains more than 1000 different items, many of which have toxic components which will have a dangerous impact on people health and environment both as a waste or during recycling, such as lead and arsenic, which exist in high percentage in old TV screens, and dioxin and trioxide antimony "or antimony" and bromide compounds existing in plastic casings, cables and electronic circuit boards, and the dangerous selenium and cadmium elements that exists in the integrated circuit boards, and chromium, which is used in shielding the steel to protect it from rust, corrosion, and cobalt, which is used in some devices to take advantage of its magnetism properties, and mercury, which can be found in keyboards and flat screens.

The first who affected by E- Waste toxic is the human and then the other environment elements (air, water, soil) where the recycling of these wastes are the main causes of environment pollution, because many health 
problems for workers in the field of recycling and burning the outer parts of the electronics will produces a lot of toxic gases, and it has an effect on global warming in the universe.

Scientific studies revealed that only four months from the date of dumping electronic devices in the waste is enough to turn them into a ticking environmental and health bomb, with this in mind we must know that each TV screen containing almost a kilo gram of lead, while there is twice of that amount in computers screen. Specialists estimate that the average weight of the desktop computer is about 32 kilograms and contains about 1.7 kilograms of lead, arsenic, cobalt, and mercury; and all these substances are toxic and pose a threat to human health and the environment.

\section{b. Risks of water and air pollution}

More than $70 \%$ of heavy metals including mercury, cadmium, tin, which reside in landfills come from electronic waste; these materials involving significant risks to the environment through leakage on to the food of animals and humans across the water when it was dumped in landfills or on the outskirts of cities. The waste of these electronic components when exposed to moisture, rain And other weather conditions leads to contamination of water and groundwater, and also the severe toxins of carbon dioxide that results from Burning these waste is the main cause of global warming and thus lead to the pollution of the air.

\section{c. Risks of contaminating soil}

using heavy metals (such as lead and mercury) in the electronics industry, And dump them in landfills and analyzed later means accumulation these element, melting and later moving into the soil and groundwater these toxic substances are leading to the deterioration of soil quality and becomes unsuitable for cultivation, and reach our food through agricultural crops and can polluting the groundwater that is close to Earth's surface

\section{TOXIC COMPONENTS OF E-WASTE}

Up to 36 different chemical elements can be found in ewaste. The most dangerous Components in electronic devices and their effects on health and environment are:

- Barium: Although the barium used to protect users from radiation generated from computer components especially computer monitors, but exposure to barium even for a short time leads to many health risks such as tumors in the human brain and the weakness of the muscles of the body and works to infect the heart, liver, and spleen.

- Chromium: Chromium is one of the most elements of a threat to the environment, it has been found that Chromium cause strong allergic reactions on humans, and asthmatic bronchitis is a common allergic reaction that is linked to chromium and may easily penetrate cells and break down the DNA( DeoxyriboNucleic Acid ).

The plastic materials in each computer contain about $6.3 \mathrm{~kg}$ 's of chromium. It has been estimated that over 315 million computers are become obsolete between 1997 and 2004, which represents about $544310 \mathrm{~kg}$ 's (544 tons) of threat hexavalent chromium.

- Phosphorus: substance covers the back of the screen to make it light up when the fall of the electronic scan, which are organic chemical components found in phosphorus panels have toxic effects cause damage to the kidneys, liver, lungs and nervous system.

- Lead: a substance has a direct impact and dangerous to the nervous system, circulatory, kidneys and immune systems of the human body as well as its negative impact on children cognitive development. Lead is concentrated in computer screens (contain $6 \%$ of lead by weight), batteries, 
computer boards and printers.

- Mercury: Mercury is one of the most toxic substances in the Materials used in the production of electrical and electronic devices causing harm to the brain, kidneys and liver damage and adversely affects the formation of the fetus if ingested or inhaled. Studies indicated that $22 \%$ of the annual consumption of mercury is through electronic equipment, medical devices, mobile phones and sensors and modern flat screens.

Mercury is commonly used in thermostats, position sensors, switches (printed circuit boards and measuring equipment), discharge lamps, some medical equipment, data transmission devices, telecommunications devices, mobile phones, and batteries.

- Inks: Printer's plastic containers are filled with color and black inks. These inks are made of the most dangerous elements is the carbon witch causes respiratory diseases and cancer as these inks contain heavy metals.

Table 1. summarizes the effects of E-Waste constituent on human health (Ali, et al., 2010).

\begin{tabular}{|c|c|c|}
\hline $\begin{array}{l}\text { Source of E- } \\
\text { Wastes }\end{array}$ & Constituent & Health effects \\
\hline $\begin{array}{l}\text { Solder in } \\
\text { printed circuit } \\
\text { boards, glass } \\
\text { panels and } \\
\text { gaskets in } \\
\text { monitors }\end{array}$ & Lead (PB) & $\begin{array}{ll}\text { - } & \text { Damage to } \\
\text { nervous } & \\
\text { systems, blood } \\
\text { systems and } \\
\text { kidney } \\
\text { damage. } \\
\text { - } \\
\begin{array}{l}\text { Affects brain } \\
\text { growth of } \\
\text { children. }\end{array} \\
\end{array}$ \\
\hline $\begin{array}{l}\text { Chip resistors } \\
\text { and } \\
\text { semiconductors }\end{array}$ & $\begin{array}{l}\text { Cadmium } \\
\text { (CD) }\end{array}$ & 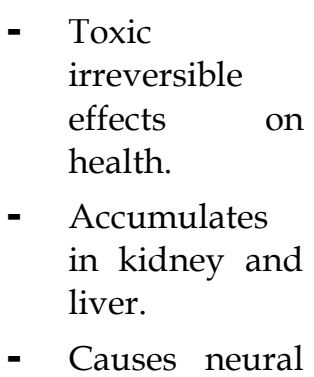 \\
\hline
\end{tabular}

\begin{tabular}{|c|c|c|}
\hline & & damage. \\
\hline $\begin{array}{l}\text { Relays, } \\
\text { switches, and } \\
\text { printed circuit } \\
\text { boards }\end{array}$ & $\begin{array}{l}\text { Mercury } \\
(\mathrm{Hg})\end{array}$ & $\begin{array}{l}\text { - Chronic } \\
\text { damage to the } \\
\text { brain. } \\
\text { - Respiratory } \\
\text { and skin } \\
\text { disorders }\end{array}$ \\
\hline $\begin{array}{l}\text { Cabling and } \\
\text { computer } \\
\text { housing }\end{array}$ & $\begin{array}{l}\text { Plastics } \\
\text { including } \\
\text { PVC }\end{array}$ & $\begin{array}{l}\text { Burning produces } \\
\text { dioxin. It causes: } \\
\text { - } \quad \text { Reproductive } \\
\text { and growth } \\
\text { problems } \\
\text { - } \text { Immune } \\
\text { system } \\
\text { damage }\end{array}$ \\
\hline $\begin{array}{l}\text { Plastic of } \\
\text { electronics and } \\
\text { circuit boards. }\end{array}$ & $\begin{array}{l}\text { Brominated } \\
\text { Flame }\end{array}$ & $\begin{array}{ll}\text { - } & \begin{array}{l}\text { Disrupts } \\
\text { endocrine }\end{array} \\
\text { system } \\
\text { functions }\end{array}$ \\
\hline $\begin{array}{l}\text { Front panel of } \\
\text { CRTs }\end{array}$ & Barium (Ba) & $\begin{array}{l}\text { Short term } \\
\text { exposure causes: } \\
\text { - Muscle } \\
\text { weakness } \\
\text { - Damage to } \\
\text { heart, liver and } \\
\text { spleen. }\end{array}$ \\
\hline Motherboard & $\begin{array}{l}\text { Beryllium } \\
\text { (Be) }\end{array}$ & $\begin{array}{l}\text { - } \begin{array}{l}\text { Carcinogenic } \\
\text { (lung cancer) }\end{array} \\
\text { - Inhalation of } \\
\text { fumes and } \\
\text { dust. Causes } \\
\text { chronic } \\
\text { beryllium } \\
\text { disease or } \\
\text { berylliosis. } \\
\text { - Skin diseases } \\
\text { such as warts. }\end{array}$ \\
\hline
\end{tabular}

\section{SIZE OF THE PROBLEM}

To know the size of the e-waste risks and the related problems on environment and public health, we must realize the size of these e-wastes and their related problems globally and locally.

Electronics such as cell phones, laptops, TVs and a growing number of other gadgets which are the reality of modern life where every day we have a new product with advanced properties, which create a strong 
desirability to own the new gadgets; hence from time to time we buy new updated products to support our needs and desires or the old devices comes at the end of their life, and in both cases the old one will be dumped.

A corollary result to this phenomenon, we will have increasingly production amount of electronic devices offset by increasingly growth of wastes of these devices, and with humble possibilities to recycle and administrate these wastes the size and risks of these wastes globally and locally are increased day by day.

In order to have solutions for these risks we must know and face the reasons of the increase growth of e-waste which can be summarized by following reasons:

- the electronics industry has become the fastest growing industries in the world lead to The increase rate of consumption of electronic devices across the world inclouding our region

- Continued decline in the life cycle for electronic devices which means that any device no matter how it was sophisticated will turn into a legacy device during a few months. This will lead in turn to the growing of e-waste volume put in landfills every day. The European Environment Agency accomplished statistical report shows that the volume of e-waste is increasing at a rate three times from the rest of the types of urban waste.

- The rapid decline in the cost of replacing the old computers and electronic devices with new ones. The continuing high rate of technical and general tendency to possess all that is a new developer. It became very rare to re-maintenance the Damaged tools because of the ease of access to the best alternative and new, and if they do not treat in the right way; they will produce toxic substances seep into the soil and groundwater to hurt the local environment and human health.
- The large increase in population and changing lifestyles has led to increase consumption of electronic devices significantly.

- The lack of awareness of the dangers of damaged electronic devices thrown in the trash piles by large numbers of people and the Lack of awareness among many people especially in undeveloped countries, of how managing the damaged or reached their end-of-life electronics and risks from throwing them in the garbage heaps

\subsection{Size of the Problem Globally}

Tens of millions of tons of discarded electronic products generated every year, this quantity of E-Waste makes up 5\% of all municipal solid waste worldwide, with nearly the same quantity of plastic and other materials used for packaging or in manufacturing the electronics which will be the cause of extra risks. For example, Asian countries discard an estimated 12 Million tons (Mt) each year hence the question will be: what about developed countries? Certainly, the quantity will be huge.

E-waste is now the fastest growing component of the municipal solid waste stream because people are upgrading their mobiles, computers, audio equipment and printers more frequently than ever before.

Many international specialized Foundations and organizations give clear indications on the size of the risks facing the humanity of this significant growth in the volume of e- waste globally; these indications can be identified through a lot of facts such as:

- In 2008 the United Nations Environment Program (UNEP), estimated that in the worldwide there are between 20 and 50 million tons of electrical and electronic goods which had come to the end of life where being thrown in Landfills every year. The latest UNEP report estimates that annual total of ewaste is 40 billion tons with America in the lead 
producing 3 million tons domestically every year followed by China with 2.3 million tons and UK total is to be more than 1 million tons which represents about 15 percent of the EU total (it is the fastest growing waste stream). But more important, the figure is starting to rise upwards, especially with huge surge of disposable electronics used in the developing countries (McCarthy, 2010)

- A United Nation report predicts that by 2020 , the ewaste in china from old computers only will jumped by 200 to 400 percent from 2007 levels, and the same holds true for South Africa, while the figure in India is 500 percent which is a staggering figure.

- At that same year in China e-waste from discarded mobile phones will be about 7 times higher than 2007 levels and, in India, 18 times. Add to that the huge quantity of e-waste Which are still imported from the countries of the world such as the US, with its corresponding dangers for human health and the environment. (McCarthy, 2010)

- Forrester Research center, issued a forecast in March 2012 and expects that the number of adults who will own a tablet device in 2016 will be 112.5 million in USA (34.3 percent of the population) and 105.7 millions in European (30.4 percent of the population) (Rotman, 2012). If that prediction proves correct, it means selling almost 293 million tablets in the six years from 2010 to 2016; this indicates the size of the e-waste that will be generated after a few years of such a large number of sold devices
- The global e-waste management market size is projected to reach USD 5.04 Billion till 2020 at an estimated CAGR (Compound Annual Growth Rate) of $20.6 \%$ between 2015 and 2020 from USD 1.66 Million in 2014 (Rohan, 2015).

- The global amount of e-waste is expected to grow to 49.8 million Tons in 2018, with an annual growth rate of $4 \%$ to $5 \%$.

Table II and Fig. 1, shows the quantity of e-waste generated, the quantity expected to be generated and the quantity generated per inhabitant (inh) between the years 2010 and 2018. (Baldé, et al., 2015)

Table II Quantity of e-waste generated and expected to be generated 2010-2018

\begin{tabular}{|c|c|c|c|}
\hline \multicolumn{3}{|c|}{ Global quantity of E-Waste Generated } \\
\hline year & $\begin{array}{c}\text { Total E- } \\
\text { Waste } \\
\text { generated } \\
(\mathrm{Mt})\end{array}$ & $\begin{array}{c}\text { Population } \\
\text { ( Billion ) }\end{array}$ & $\begin{array}{c}\text { generated } \\
\text { by } \\
\text { inhabitant } \\
\text { (kg/inh })\end{array}$ \\
\hline 2010 & 33.8 & 6.8 & 5.0 \\
\hline 2011 & 35.8 & 6.9 & 5.2 \\
\hline 2012 & 37.8 & 6.9 & 5.4 \\
\hline 2013 & 39.8 & 7.0 & 5.7 \\
\hline 2014 & 41.8 & 7.1 & 5.9 \\
\hline 2015 & 43.8 & 7.2 & 6.1 \\
\hline 2016 & 45.7 & 7.3 & 6.3 \\
\hline 2017 & 47.8 & 7.4 & 6.5 \\
\hline 2018 & 49.8 & 7.4 & 6.7 \\
\hline
\end{tabular}

$\mathbf{M t}=$ Million tons, $\mathbf{i n h}=$ inhabitant, $\mathbf{k g}=$ kilogram

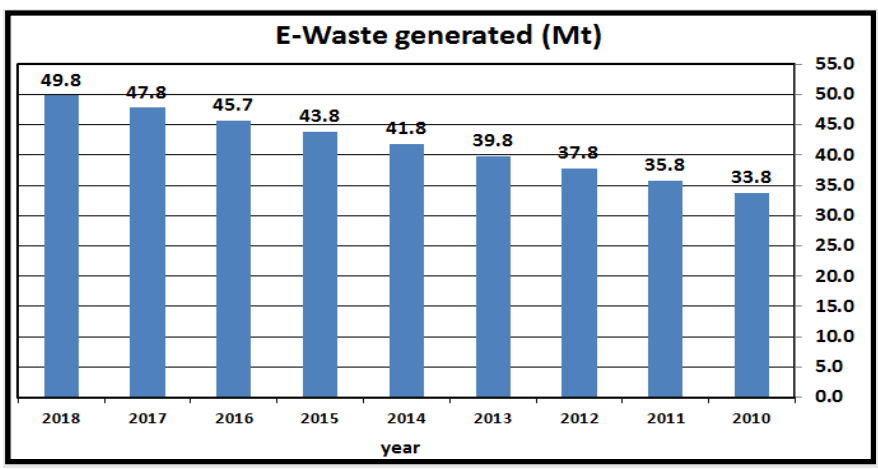

Fig. 1. Total e-waste generated and expected to be generated 2010-2018 
Table III and Fig. 2, shows the size of e-waste problem in some selected countries in 2014 (USA and China are the worst countries in generating e-waste) (Baldé, et al., 2015).

Table III Size of the e-waste problem in some countries in 2014

\begin{tabular}{|l|c|c|c|}
\hline \multirow{2}{*}{ Country } & \multicolumn{2}{|c|}{ E-waste Generated } & \multirow{2}{*}{$\begin{array}{c}\text { population in } \\
\text { Million }\end{array}$} \\
\cline { 2 - 3 } & $\begin{array}{c}\text { Kotal } \\
\text { (Mt) }\end{array}$ & 0.03 & 6.7 \\
\hline Jordan & 4.5 & 0.07 & 4.0 \\
\hline Egypt & 17.2 & 0.37 & 85.8 \\
\hline Lebanon & 9.4 & 0.04 & 4.1 \\
\hline UAE & 17.2 & 0.10 & 5.9 \\
\hline Saudi Arabia & 12.5 & 0.38 & 30.3 \\
\hline Turkey & 6.5 & 0.50 & 76.7 \\
\hline USA & 22.1 & 7.07 & 319.7 \\
\hline China & 4.4 & 6.02 & 1367.5 \\
\hline India & 1.3 & 1.63 & 1255.6 \\
\hline Germany & 21.7 & 1.77 & 81.6 \\
\hline Iran & 7.4 & 0.58 & 78.1 \\
\hline UK and & 17.6 & 1.08 & 61.2 \\
\hline Northern & 23.5 & & 127.1 \\
\hline Ireland & 17.3 & 2.20 & 64.3 \\
\hline Italy & & 1.51 & \\
\hline Japan & & & \\
\hline
\end{tabular}

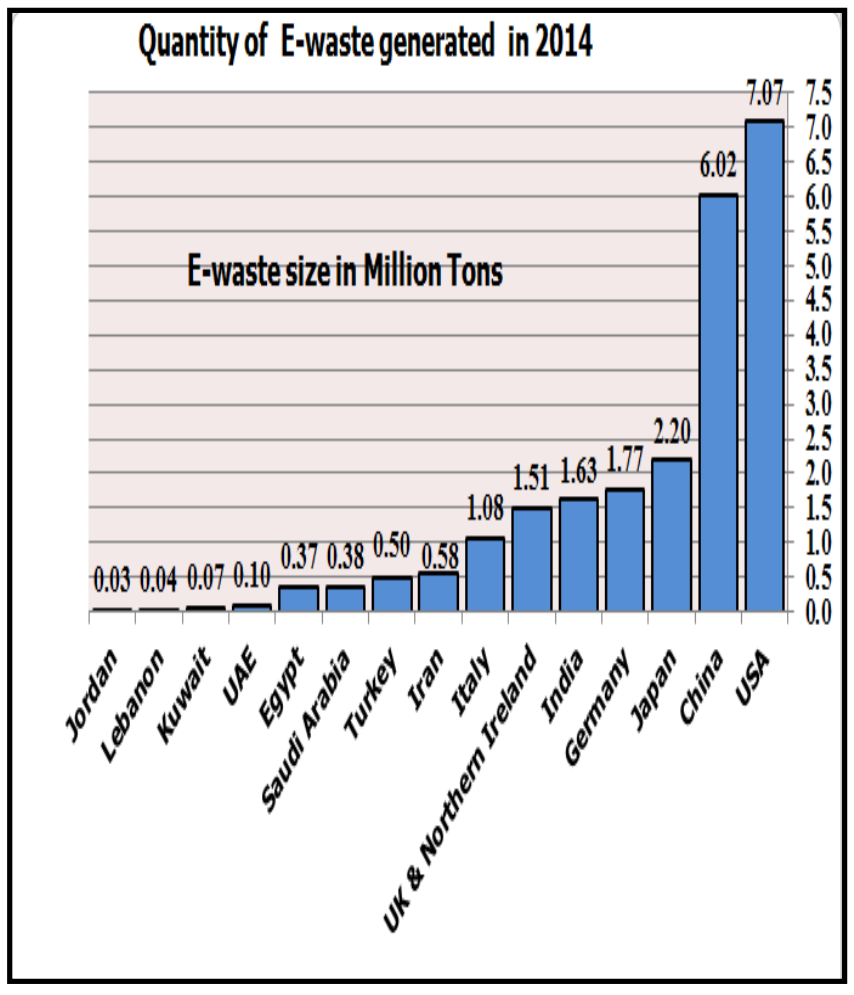

Fig. 2. Quantity of e-waste generated in some countries in 2014

\subsection{Size of the Problem Locally}

Kurdistan region of Iraq as part of this world must be influenced by the technological revolution that swept the world during the last century which had radically changed people's lifestyle in the region which led therefore to a larger sections of the society that become able to purchase the new products regardless of their needs especially if we know that the region since 1992 lived a clear economic development that led to a distinct change in the consumption patterns of citizens in the region and the entry of very large amounts of electronic appliances from multiple origins to meet the desires of the citizens that characterized by the movement towards the continuous replacement their assets of these devices especially computers and Mobiles accompanied by the absence of the role of the government in monitoring the origins of these devices which are exposed to consumption early because of a lack -of-life of these devices. All of these factors led to a 
marked accumulation of electronic devices in homes and in the maintenance workshops and then transition to landfills in the form of e-waste to affect negatively on the environment and the health of citizens.

On the other hand, and despite of the fact that the Ministry of Environment of the Kurdistan Regional Government issued Law No (8) for the year 2008 and approved by the Kurdistan Parliament in 11/11/2008. the fifth paragraph of the third section of that law, dedicated for hazardous substances and recycling of garbage, and the items $(34,35,36)$ speaks clearly on this issue to prevent any person or entity to manufacture , store, transport, importation, or burial any material that may contaminated the environment in general except under special instructions from the ministry and in coordination with the concerned authorities, but this law has not been activated, and follow-up effectively by the relevant departments in order to face this threat to the citizens of the region and its environment such as the participation of the Ministry in international conferences like Basel and Kyoto because it is still restricted and tied with central government.

Table IV gives an idea about the e-waste in Iraq in 2014 (Baldé, et al., 2015).

Table IV: Size of the e-waste problem in Iraq in 2014

\begin{tabular}{|l|c|c|}
\hline \multicolumn{1}{|c|}{ Subject } & Unit & Amount \\
\hline Population & $\begin{array}{c}\text { (total inhabitants in } \\
\text { million) }\end{array}$ & 35.8 \\
\hline E-waste & (Kg per inhabitant) & 3.1 \\
\cline { 2 - 3 } generated & (total in $\mathrm{Kt})$ & 112 \\
\hline
\end{tabular}

\section{Materials and Methods}

The data needed for the investigation and analysis of the e-waste negative effects was obtained from statistical questionnaire made from views of 280 citizens in Duhok city. Only 272 acceptable questionnaires were retrieved. These citizens were chosen randomly from various sectors of society in Duhok city including students, housewives, technicians of electronic devices, employees and others.

The objective of these questionnaires is to identify the level of awareness of the citizens regarding the increasing amount and risks of e-waste on the environment and public health. The role of the government in treating the problem of e-waste was also considered as a part of the questionnaire contents. The questionnaires included questions regarding the following:

- The levels of Duhok citizens knowledge concerning e-waste and its risks on health and environment

- The unaware behaviors carried out by Citizens, companies and electronics maintenance Workshops that led to the growth of the volume of e-waste in an inconvenient manner.

- The role of government in educating the citizens for how to treat this e-waste in such a way to make the harms of this e-waste on the health and environment as small as possible.

- The citizen satisfaction about the after-sales services that the companies of electronic devices can offer.

- The citizen reaction to the proper (positive) treatment of this e-waste by the government and how good this e-waste can be recycling by the government.

- The role and willing of the citizens in cooperating with the government strategies for e-waste treatment.

Accordingly, the questionnaire included eight specific questions which need short answers "yes" or "no". This will facilitate the task of the questionnaire distributors 
to answer enquiries about the questionnaire in order to avoid citizen confusion and to guarantee proper answers by citizens. These eight questions are shown in Table V.

\begin{tabular}{|c|c|c|c|}
\hline $\begin{array}{c}\text { rid of electronic } \\
\text { devices reached to } \\
\text { their end-of-life }\end{array}$ & Yes & 82 & $94 \%$ \\
\hline
\end{tabular}

Table V: Questionnaire questions

\section{Results and discussion}

The analysis of the questionnaire data for each question was based on the relative frequency of the answers made by surveyed people. The results obtained are summarized in table VI.

Table VI: The results of the answers on the questionnaire questions

\begin{tabular}{|c|c|c|c|}
\hline Questions & $\begin{array}{c}\text { Answer } \\
\text { options }\end{array}$ & $\begin{array}{c}\text { Number } \\
\text { of } \\
\text { answers }\end{array}$ & $\begin{array}{c}\% \text { of the } \\
\text { answers }\end{array}$ \\
\hline $\begin{array}{c}\text { Q1. Do you know } \\
\text { anything about the } \\
\text { term " e-waste " }\end{array}$ & Yes & 87 & $32 \%$ \\
\cline { 2 - 4 } & No & 185 & $68 \%$ \\
\hline
\end{tabular}

The remaining questions are for the citizens who answer by (yes) on Q1

\begin{tabular}{|c|c|c|c|c|}
\hline \multirow{2}{*}{\multicolumn{2}{|c|}{$\begin{array}{l}\text { Q2. Do you think that } \\
\text { there is a } \\
\text { significant } \\
\text { increase of e- } \\
\text { waste, whether at } \\
\text { homes or in } \\
\text { landfills or in } \\
\text { electronic devices } \\
\text { maintenance } \\
\text { workshops } \\
\end{array}$}} & Yes & 71 & $82 \%$ \\
\hline & & No & 16 & $18 \%$ \\
\hline \multirow[t]{2}{*}{ Q3. } & \multirow{2}{*}{$\begin{array}{l}\text { Do you throw the } \\
\text { damaged } \\
\text { electronic devices } \\
\text { in the public waste } \\
\text { containers }\end{array}$} & Yes & 83 & $95 \%$ \\
\hline & & No & 4 & $5 \%$ \\
\hline \multirow[t]{2}{*}{ Q4. } & \multirow{2}{*}{$\begin{array}{l}\text { Do you have } \\
\text { knowledge about } \\
\text { the degree of e- } \\
\text { waste risks on } \\
\text { environment and } \\
\text { health }\end{array}$} & Yes & 14 & $16 \%$ \\
\hline & & No & 73 & $84 \%$ \\
\hline \multirow[t]{2}{*}{ Q5. } & \multirow{2}{*}{$\begin{array}{l}\text { Are you satisfied } \\
\text { with measures } \\
\text { taken by DUHOK } \\
\text { governorate to } \\
\text { face the risks of e- } \\
\text { waste }\end{array}$} & Yes & 83 & $5 \%$ \\
\hline & & No & 4 & $95 \%$ \\
\hline \multirow[t]{2}{*}{ Q6. } & \multirow{2}{*}{$\begin{array}{l}\text { Are you satisfied } \\
\text { with after-sale } \\
\text { services offered by } \\
\text { electronics } \\
\text { companies to get }\end{array}$} & Yes & 7 & $8 \%$ \\
\hline & & No & 80 & $92 \%$ \\
\hline
\end{tabular}

\begin{tabular}{|c|}
\hline Questions \\
\hline Q1. Do you know anything about the term "E-waste "? \\
\hline $\begin{array}{c}\text { Q2. Do you think that there is a significant increase of e- } \\
\text { waste, whether at homes or in landfills or in } \\
\text { electronic devices maintenance workshops? }\end{array}$ \\
\hline
\end{tabular}

Q3. Do you throw the damaged electronic devices in the public waste containers?

Q7.Q4. Dou you shpperthowledge about the degree of e-waste the distribution $\mathrm{of}_{\mathrm{f}}$ on environment and health? special containers

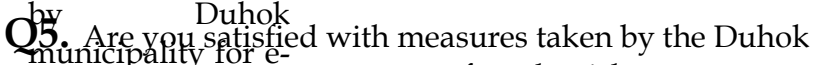
waste to the ernorate to face the risks

citizens to reduce of E-waste?

its risks

Q6. Are you satisfied with after-sale services offered by electronics companies to get rid of electronic devices reached to their end-of-life?

Q7. Do you support the distribution of special containers by Duhok municipality for e-waste to the citizens to reduce its risks?

Q8. Do you think that there is a need to establish awareness campaigns for citizens to define the dangers of e-waste and how to deal with it?

\begin{tabular}{|l|l|l|l|}
\hline & No & 5 & $6 \%$ \\
\hline Q8. Do you think that \\
$\begin{array}{l}\text { there is a need to } \\
\text { establish } \\
\text { awareness } \\
\text { campaigns for } \\
\text { citizens to define } \\
\text { the dangers of e- } \\
\text { waste and how to } \\
\text { deal with it }\end{array}$ & No & 78 & $90 \%$ \\
\hline
\end{tabular}

As an example, Fig. 3 shows the results of the citizens' 
answers on the first question (Q1) of the questionnaire

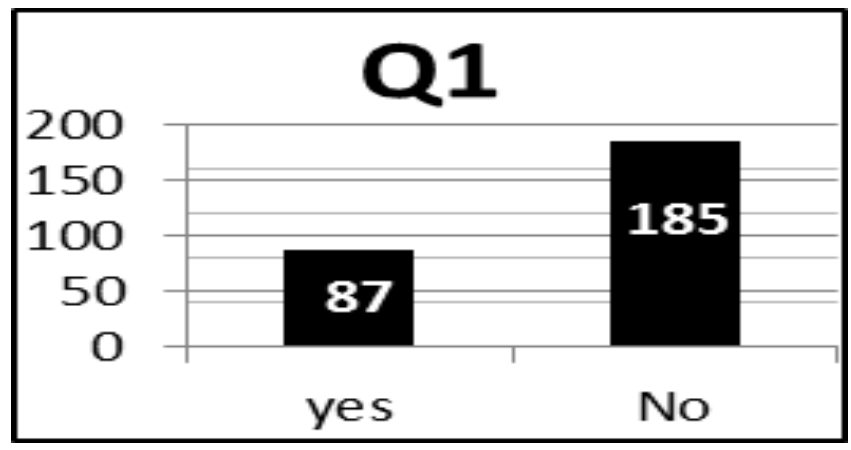

Fig. 3. Answers of citizens on the first question (Q1) of the questionnaire

The results of survey implemented by the researcher demonstrated that:

- $\quad$ Refer to (Q1), 68\% of surveyed people which is equivalent to (185 persons) did not know the meaning of e-waste. This indicates a clear ignorance of the dangerous effects of e-waste among a large sector of society.

- Refer to (Q2), the rest of surveyed citizens, which are equivalent to ( 87 persons) have the knowledge concerning the e-waste but showed different views and responses to this issue. These views are shown below:

O $82 \%$ of these 87 persons shown significant awareness for the increase of e-waste both, at home, in landfills and in electronic devices maintenance workshops.

○ $95 \%$ of these 87 persons unfortunately contribute to the increase of e-waste through some negative activities that lead to throwing damaged appliances in public waste containers. This might be due to either the lack of awareness among the citizens of the dangers throwing the damaged devices in the public waste containers or it might be due to the unavailability of dedicated e-waste containers at the reliable places, (role of government).

○ $84 \%$ of these 87 persons shown Lack of awareness about sever danger of e-waste on environment and health. This demands the intervenient of the environment and health departments in Dohuk governorate to pay attention for establishing special workshops to minimize the dangers of ewaste.

○ $95 \%$ of respondents are dissatisfied with the performance and the policies of government towards the treatment of ewaste. This requires that the government to review its programs to face e-waste risks and finding appropriate solutions for its increasing growth. 
○ $92 \%$ of people surveyed are dissatisfied with the after-sale services offered by electronics companies in maintaining and get rid of old electronic devices. This suggests that the Duhok governorate must follow up the electronics company's obligations towards the clients. This may include introducing of a special Regulations and policy for after-sales services.

○ $94 \%$ of participants suggest that Duhok municipality offices must distribute special containers for the collection of e-waste and to must urge the citizens to comply with government instructions for using these containers properly and throwing the damaged devices in these containers to reduce its risks

$90 \%$ of participants expressed good willingness to cooperate with the government in getting rid of ewaste to reduce its risks through participating in training courses and awareness campaigns organized by the government for how to deal with e-waste.

\section{Conclusion}

A careful study of the figures obtained from the survey conducted by the researcher on a sample of the citizens of the province of Duhok in Kurdistan region of Iraq, we can deduce the following facts about the e-waste and their serious impact on the environment and public health:

- The study has shown a general shortage in treating and administrating the problem of e-waste. Despite, there has been a governmental Law. No. 8, issued in 2008, for environment protection in Kurdistan Region of Iraq, it seems that this law has not been applied and following-up by the concerning sectors of the government. The ignorance of applying this law constitutes one of the major reasons behind the lack of people care about the risks of e-waste.

- The study has shown that most sectors for the society require serious awareness and education towards the negative effects of e-waste and how to minimize the harmful effects on public health and environment, this can be provided through educational programs held by Concerned departments in the government and civilian organization such as schoolsg universities and Civil society organizations.

- The existence of shortening by importers of electronic devices with regard to after-sales services and failure to perform their required duties and roles in helping the citizens to rid of old electronic devices After replacing the old devices with new ones and then find solutions for how deal with devices which are recovered from citizens.

- The lack of government controls over the imported electronics led the markets to be full of Harmful devices from bad origins. This in turns has led to the accumulation of e-waste.

- There is a desire and willingness of the citizens in Duhok city towards the cooperation with the 
government to get rid of these wastes and managing them.

- The lack of a clear policy and experience in government departments in the proper way to dispose these wastes or recycle them for beneficial purposes rather than facing their risks.

- More roles and contributions are required from the civil society organizations and institutions to educate citizens about the dangers of e- waste and how to deal with it.

\section{Recommendations}

Based on the aforementioned conclusions, several recommendations can be suggested in order to find appropriate solutions to minimize the growth of ewaste and reducing its risks on the health of citizens and the environment in Kurdistan region of Iraq:

- The regional government must activate the Environmental Law No. (8), which was issued in 2008 in order to put some restrictions on the imported electronics Especially used and shoddy types. these restrictions may include how to control the quality of the imported electronics which can be done via the customs departments to monitor border crossings to ensure the quality of electronic products that are imported into the region with deterrent fines on traders who import devices which are hazardous to the environment and health.

- The region government must issue laws and regulations governing the operations of the managing and recycling of this hazard waste and try to build specialized centers and factories to utilize the recycled waste and the provision of special sanitary landfills for such wastes in accordance to the international standards confirmed by specialized international organizations.

- The region government must follow a wellorganized strategy for how to make contact with importers and sellers of electronics through industry and commerce chambers to raise the level of their awareness and knowledge about the dangers of importing devices from bad origins which has harmful impact on public health and environment by organization of special meetings and training courses.

- There must be greater roles of the printable, audible, and visual media in educating citizens about the seriousness of e-waste and how to handle them carefully when discarded it.

- The need for to conduct a comprehensive study to evaluate the situation of the e-waste in the region with collaboration between universities, health and environmental departments, government and civil society organizations in order to reach national action plans for how to cope with the risks of such waste in the future

- The need for attention to establish and develop of the environmental and health institutions (governmental and private) which are interested on how to confront the dangers of wastes and establishment of informative seminars and training courses for employees of these institutions to do their part in preparation of educational and awareness programs for the citizens of the region.

- There must better cooperation between the public, private sectors and civil society organizations in this field to reduce the risk of these wastes.

- The teaching curriculum of schools and universities must include some concepts about e-waste in order to develop the knowledge amonge citizens about ewaste dangers and the treatment methods. 
- Create specialized Web sites in Multi-lingual with a focus on Kurdish language to raise the level of awareness and knowledge of the citizens about the risks of these e-wastes and the Correct methods in dealing with damaged devices

- Creation of chances for the employees in health and environmental institutions to participate in international conferences to get more experiences for how to manage e-waste and related problems.

\section{Acknowledgement}

It's my pleasure to express my gratitude to those who supported me throughout the preparation of this work. In particular, I would like to express my deep thanks to the citizens who responded to questionnaires about this work. Thanks also are due to all my friends and colleagues for their valuable notes and advices, especially Mrs. Tallo and Mr. Thaker for their help in distributing the questionnaires. Last but not least, I would like to thank Dr. Alyousif for his valuable notes in designing the questionnaire.

\section{References}

1. Ali, A. A., Gitau A. N., Hassan M. A., Gumbe L. O. and Gichuki N. N., 2010.Household waste generation and management practices in Nairobi. Waste Management journal (Elsevier), (30), pp. 1752-1755.

2. Baldé, C. P., Wang, F. , Kuehr R. and Huisman J., 2015.The global e-waste monitor - 2014.United Nations University, IAS - SCYCLE, Bonn, Germany. Available at:

3. http://i.unu.edu/media/unu.edu/news/52624/UNU1stGlobal-E-Waste-Monitor-2014-small.pdf

4. Marie-Noël, Drisse B., 2015.E-waste and Women's Health. Department of Public Health, Environmental and Social Determinants of Health World Health Organization, ITU, Geneva, Available at: https://www.itu.int/net4/wsis/forum/2015/Uploads/ S/190/MarieNoelBRUNE_WHO.pdf

5. McCarthy, M. 2010. The Big Question: How big is the problem of electronic waste, and can it be tackled?, Available at: http://www.independent.co.uk/environment/greenliving/the-big-question-how-big-is-the-problem-ofelectronic-waste-and-can-it-be-tackled1908335.html (Accessed: 24 February 2010).

6. Harjula, H., 2003. How To Apply Environmentally Sound Management To Small And Medium Size Enterprises, Case Study: Pre-treatment and Recovery of Waste Electric and Electronic Equipment's (WEEE)), 3rd Workshop on Environmentally Sound Management (ESM) of Wastes Washington D.C.: OECD (Organization for Economic Co-operation and Development). Available at:

http://www.oecd.org/officialdocuments/publicdisplay documentpdf $/$ ?doclanguage $=$ en\&cote $=$ env $/$ epoc $/ W G W$ PR/RD (2002)6/FINAL

7. Richard C. Porter, 2002.The Economics of Waste, by Resources for the Future, Washington D.C, Resources for the Future

8. Puckett J., Byster L., Westervelt S., Gutierrez R., Davis S., Hussain A. and Dutta M., 2002. Exporting Harm: The High-Tech Trashing of Asia, Kowloon, Hong Kong. API Recycle. Available at: http://svtc.org/wpcontent/uploads/technotrash.pdf

9. Rohan,, 2015. E-Waste Management Market by Material Recovery (Metals, Plastic, \& Glass), Source type (Household Appliances, Entertainment \& Consumer Electronics, \& IT \& Telecommunication), and by Geography - Forecast to 2020, Dublin 8, Ireland: Markets and Markets. Available at: http://www.researchandmarkets.com/reports/3333401 /e-waste-management-market-by-material-recovery\# description

10. Rose, C. M., Stevels, A. and Ishii, K., 2002.Method for Formulating Product End-Of-Life Strategies for Electronics Industry. Journal of Electronics Manufacturing, 11(2), pp. 185-196.

11. Rotman S. E., 2012. US Consumer Tablet Forecast Update, 2011 To 2016. Cambridge, USA: Forrester Research, Inc. Available at:

http:/cn.cnstudiodev.com/uploads/document_attachme 
nt/attachment/199/usconsumer_tablet_foreca.pdf

12. Acharya S., Kern M. 2015.UN system collaborates on electronic waste disposal, ITU and Secretariat of the Basel Convention to protect environment from hazardous eWaste. Geneva, ITU. Available at:

http://www.itu.int/net/pressoffice/press_releases/201

2/CM01.aspx\#.WDSz6dJ97Mx

13. Jailer T., Lara-Meloy M., and Robbins M. 2015.Workers' Guide to Health and Safety. Berkeley, California, USA: Hesperian Health Guides. Available at:

https://hesperian.org/wpcontent/uploads/pdf/en_wgthas_2015/en_wgthas_2015 _33.pdf 